\title{
Peranan Diplomat Indonesia dalam Memperjuangkan Palestina di PBB (Masa Presidency of the UNSC Mei 2019)
}

\section{Teuku Rezasyah}

Program Studi Hubungan Internasional, Fakultas IImu Sosial dan Ilmu Politik, Universitas Padjadjaran e-mail: teuku.rezasyah@unpad.ac.id

\begin{abstract}
In May 2019, Indonesia served as President of the UN Security Council. During her presidency, Indonesia sought to achieve world peace by raising the theme "Investing in Peace." This research seeks to explain the role of Indonesian diplomats in defending Palestine during the presidency especially in the issue of Israeli illegal settlements in the West Bank. The research was conducted qualitatively by examining official documents and mass media, as well as conducting interviews with primary informant. The concept used in this research is national role conception from Holsti. This research finds that Indonesian diplomats carry out their role in fighting for Palestine driven by the national role conception as the bastion of revolution liberator or as a nation that wants to abolish colonialism in another country, namely Palestine.
\end{abstract}

Keywords: diplomacy, illegal settlement, Indonesia, national role conception, Palestine

\section{Abstrak}

Pada bulan Mei 2019, Indonesia menjabat sebagai Presiden Dewan Keamanan PBB dan selama satu bulan penuh masa kepresidenannya, Indonesia berupaya untuk berkontribusi dalam mewujudkan perdamaian dunia dengan mengangkat tema "Investing in Peace". Artikel ini menjelaskan peran yang 
dilakukan diplomat Indonesia dalam membela Palestina selama masa presidensi tersebut, terutama terkait dengan berlanjutnya pembangunan permukiman ilegal Israel di Tepi Barat. Riset dilakukan secara kualitatif dengan menelaah dokumen resmi maupun media massa, serta melakukan wawancara dengan narasumber primer. Konsep yang digunakan dalam riset ini adalah national role conception dari Holsti. Temuan penelitian ini adalah bahwa para diplomat Indonesia menjalankan perannya dalam memperjuangkan Palestina didorong oleh national role conception sebagai bastion of revolution liberator atau sebagai bangsa yang ingin menghapuskan penjajahan di negara lain, yaitu Palestina.

Kata kunci: diplomasi, Indonesia, konsep peran nasional, Palestina, permukiman ilegal

\section{Pendahuluan}

Hubungan Republik Indonesia dan Palestina dapat dikatakan sebagai sebuah hubunganyang sangat istimewa karena mempertautkan pemerintah dan masyarakat Indonesia dalam sebuah kesepakatan yang terus-menerus, yakni memperjuangkan tujuan nasional Indonesia di tingkat dunia, guna turut menciptakan perdamaian yang abadi. Seluruh pemerintahan Indonesia sejak awal kemerdekaannya di tahun 1945, senantiasa menolak untuk mengakui negara Israel, sampai terwujudnya sebuah pemerintahan Palestina yang berdaulat. Karena itulah, pemerintah Indonesia tiada hentinya mendukung Palestina, dan menggelorakan semangat ini dalam berbagai forum internasional yang diawakinya. Di tingkat masyarakat Indonesia sendiri, kegiatan peribadatan di kalangan masyarakat Islam senantiasa memasukkan kata kunci 'Palestina' dalam berbagai doa di masjid, langgar, dan pengajian umum. Tidak terhitung perguruan tinggi yang secara teratur membedah situasi terkini di Palestina. Duta Besar Palestina di Jakarta pun secara rutin mengunjungi berbagai kampus dan organisasi kemasyarakatan di dalam negeri Indonesia.

Pada berbagai era pemerintahannya, sejak era Sukarno hingga era Joko Widodo, Republik Indonesia secara mandiri dan dalam kapasitasnya sebagai pemimpin di berbagai organisasi kerjasama regional dan internasional, telah bekerja keras menggalang pengakuan dari banyak negara untuk mengakui kemerdekaan Palestina. Hingga bulan September 2015, tercatat 136 negara dari 193 anggota PBB yang telah mengakui Palestina sebagai negara. Bahkan di benua Eropa, jumlah negara yang mendukung Palestina terus bertambah (Ministry of Foreign Affairs of 
the Republic of Indonesia, 2019). Pada tanggal 29 November 2012, Palestina resmi disahkan sebagai non-member observer state PBB melalui Resolusi Majelis Umum PBB No. 67/19, di mana Indonesia bertindak sebagai co-sponsor resolusi tersebut. Selanjutnya pada tanggal 30 September 2015, bendera Palestina resmi berkibar di Markas Besar PBB di New York, yang disaksikan langsung oleh Presiden Mahmoud Abbas (BBC, 2015).

Indonesia sebelumnya menjadi Co-Chairs (Ketua Bersama) bersama Republik Afrika Selatan dalam mekanisme New Asia-Africa Strategic Partnership (NAASP). Indonesia menangani kawasan Asia, sementara Afrika Selatan menangani kawasan Afrika. Melalui program NAASP, Indonesia menjadi tuan rumah serta penggagas NAASP Ministerial Conference on Capacity Building for Palestine pada tahun 2008. Pada pertemuan tersebut disepakati untuk memberikan bantuan program pembangunan kapasitas bagi 10.000 warga Palestina dalam kurun waktu 5 tahun (2008-2013), yang dipraktikkan dalam berbagai lembaga pendidikan dan lembaga kedinasan di dalam negeri Asia dan Afrika. Pada kesempatan tersebut juga Presiden Susilo Bambang Yudhoyono menyampaikan komitmen Indonesia untuk memberikan pelatihan kepada 1.000 warga Palestina. Selaku ketua bersama NAASP, Indonesia dan Afrika Selatan mengadakan pertemuan dengan negara-negara anggota lainnya. Pada tahun 2014, keduanya melakukan evaluasi dari kerjasama NAASP di tahun-tahun sebelumnya. Hasilnya adalah dibutuhkannya penguatan (Kemenlu, 2019a).

Komitmen RI dalam membantu perjuangan kemerdekaan bangsa Palestina terus terlihat hingga era pemerintahan terkini yang dipimpin oleh Presiden Joko Widodo. Dalam peringatan 60 tahun Konferensi Asia Afrika di Bandung tanggal 24 April tahun 2015, Presiden Joko Widodo mengingatkan bahwa komunitas internasional masih berhutang pada Palestina. Berikut ini kutipan pidato Presiden Joko Widodo:

Kita dan dunia masih berutang kepada rakyat Palestina. Dunia tidak berdaya menyaksikan penderitaan rakyat Palestina yang hidup dalam ketakutan dan ketidakadilan akibat penjajahan yang berlangsung begitu lama.

Kita tidak boleh berpaling dari penderitaan rakyat Palestina, kita harus terus berjuang bersama mereka. Kita harus mendukung lahirnya sebuah negara Palestina yang merdeka. (tribunnews.com, 2015)

Indonesia juga aktif mengawal rancangan resolusi PBB mengenai pengibaran bendera Palestina yang masih berstatus sebagai negara pengamat (observer) di 
kantor PBB. Akhirnya, pada 10 September 2015 Resolusi Majelis Umum PBB tentang Pengibaran Bendera Negara-negara Observer di Kantor Perserikatan Bangsa-Bangsa disahkan. Untuk pertama kalinya bendera Palestina pun berkibar di markas PBB di New York pada tanggal 30 September 2015 (Siadari, 2015).

Puncaknya, ketika Indonesia mendapatkan kesempatan untuk menjabat sebagai anggota Dewan Keamanan PBB periode 2019-2020, khususnya ketika pada bulan Mei 2019 Indonesia menjabat sebagai Presiden Dewan Keamanan PBB dan memiliki kesempatan untuk memimpin berbagai persidangan di Dewan Keamanan, Indonesia memanfaatkannya secara maksimal untuk menyuarakan dukungan kepada perjuangan Palestina demi mendapatkan haknya sebagai negara berdaulat. Selama masa presidensinya, Indonesia mengangkat tema "Investing in Peace", di mana Indonesia berusaha menarik perhatian komunitas internasional untuk kembali peduli kepada berbagai isu yang sangat penting demi menciptakan perdamaian dunia. Para diplomat Indonesia di PBB mengadakan Arria-Formula Meeting on the Palestinian Issue yang menekankan pentingnya dunia internasional menyelesaikan kasus pelanggaran hukum internasional di Palestina yaitu pembangunan permukiman ilegal (illegal settlements) di kawasan pendudukan Palestina.

Dalam artikel ini, penulis akan membahas lebih dalam bagaimana para diplomat Indonesia memperjuangkan Palestina di PBB dan menganalisisnya dengan menggunakan konsep peran nasional (national role conception) yang dikemukakan oleh Holsti. Selanjutnya uraian dalam artikel ini akan dibagi ke dalam sejumlah bagian, yaitu deskripsi singkat mengenai national role conception, penjelasan singkat mengenai sejarah konflik Palestina-Israel, problem illegal settlement, dan faktor Amerika Serikat; paparan mengenai peranan diplomat Indonesia dalam memperjuangkan Palestina di PBB pada masa presidensi di DK PBB, dan ditutup dengan kesimpulan.

\section{Konsepsi Peran Nasional (National Role Conception)}

Dalam hasil riset yang dipublikasikan tahun 1970, Holsti menjelaskan adanya empat konsep peran yang dapat membantu para penstudi dalam menganalisis kebijakan luar negeri sebuah negara (Holsti, 1970: 233-309), yaitu:

(1) role performance, yaitu perilaku kebijakan luar negeri dari sebuah pemerintahan, yang meliputi pola perilaku, keputusan, respon, fungsi, dan komitmen terhadap negara lain 
(2) self-defined national role conceptions, yaitu konsep peran nasional yang didefinisikan sendiri oleh elit pengambil kebijakan di sebuah negara, Konsepsi nasional itu bersumber dari lokasi negara, sumber daya alam yang dimiliki, kebutuhan sosial-ekonomi, nilai, ideologi, opini publik, kepribadian, dan kebutuhan politik.

(3) the role prescriptions, yaitu peran yang dipengaruhi oleh faktor eksternal, bersumber dari sistem/struktur internasional beserta nilai di dalamnya, prinsip-prinsip hukum umum, komitmen terhadap perjanjian internasional, dan pemahaman informal atas opini dunia.

(4) posisi negara, atau perkiraan sebuah negara atas posisinya di tengah sistem internasional dan apa konsekuensi atas pilihan kebijakan yang diambilnya.

Setelah melakukan penelitian terhadap konsep peran nasional berbagai negara di dunia, Holsti mengidentfikasi ada 17 konsep peran nasional, yaitu bastion of revolution-liberator, regional leader, regional protector, active independent, liberation supporter, anti-imperialist agent, defender of the faith, mediator-integrator, regionalsubsystem collaborator, developer, bridge, faithful ally, independent, example, internal development, isolate, dan protectee. Holsti menyimpulkan bahwa Indonesia (bersama China, Cuba, dan Korea Utara) termasuk ke dalam kelompok negara yang memiliki konsep peran nasional sebagai bastion of revolution liberator, dan sumber dari konsep peran nasionalnya adalah ideological principles, anti-colonial attitudes, dan desire for ethnic unity.

Definisi yang diberikan secara lebih rinci oleh Holsti untuk kategori bastion of revolution-liberator adalah sebagai berikut:

"Some governments hold that they have a duty to organize or lead various types of revolutionary movements abroad. One task of their state, as they see it, is to liberate others or to act as the "bastion" or revolutionary movements, that is, to provide an area which foreign revolutionary leaders can regard as a source of physical and moral support, as well as an ideological inspirer." (Holsti, 1970: 260-261).

Perlu diingat bahwa Holsti melakukan penelitiannya pada tahun 1965-1967, yaitu di masa peralihan antara Orde Lama, di bawah pimpinan Sukarno, ke masa Orde Baru dan sistem internasional saat itu berada di era Perang Dingin. Kini, 52 tahun telah berlalu, mungkin ada perubahan dalam konsepsi peran nasional yang dimiliki Indonesia; namun mungkin juga tidak ada perubahan bila dikaitkan dengan isu Palestina. Dalam artikel ini, penulis akan berupaya memaparkan prinsip-prinsip 
ideologis (ideological principles) dan perilaku antikolonial (anti-colonial attitudes) Indonesia dalam membela Palestina, untuk melihat apakah national role conception Indonesia dalam isu ini masih tetap sama dengan kondisi 52 tahun yang lalu.

\section{Paparan Singkat Mengenai Konflik Palestina-Israel}

Palestina adalah salah satu bekas wilayah Imperium Ottoman yang diserahkan kepada pemerintahan Inggris oleh Liga Bangsa-Bangsa pada tahun 1922 (pasca kekalahan Ottoman dalam Perang Dunia I). Sebelumnya, pada tahun 1917, Menteri Luar Negeri Inggris, Balfour, telah memberikan deklarasi dukungan untuk"pendirian rumah nasional bagi rakyat Yahudi di Palestina". Karena itulah selama era mandat Inggris atas Palestina (1922-1947), di Inggris dilakukan imigrasi besar-besaran kaum Yahudi, terutama dari Eropa Timur, ke Palestina. Kedatangan imigran Yahudi semakin banyak pasca terjadinya Holocaust di Jerman pada tahun 1930-an.

Bangsa Arab Palestina pada masa itu angkat senjata untuk menuntut kemerdekaan dari Inggris, sekaligus menentang gelombang migrasi besar-besaran kaum Yahudi. Pada tahun 1947, Inggris menyerahkan masalah Palestina ke PBB. PBB kemudian mengeluarkan Resolusi 181 tahun 1947 yang mengakhiri era mandat Inggris dan membagi Palestina menjadi dua negara merdeka, yaitu negara Arab Palestina dan negara khusus Yahudi, sedangkan kota Yerusalem menjadi wilayah internasional. Kaum Yahudi kemudian memproklamasikan berdirinya negara Israel pada Mei 1948, sedangkan pembentukan Palestina terhalang akibat berbagai perang dan pendudukan. Pada perang 1967, Israel menduduki wilayah-wilayah yang ditetapkan Resolusi 181 sebagai wilayah negara Palestina (Jalur Gaza dan Tepi Barat) dan Yerusalem Timur.

Akibat peperangan itu sekitar setengah juta warga Palestina menjadi pengungsi. Dewan Keamanan PBB mengeluarkan Resolusi 242 yang merumuskan prinsipprinsip perdamaian yang adil dan abadi, termasuk penarikan Israel dari wilayahwilayah yang diduduki dalam konflik, penyelesaian masalah pengungsi dengan adil, dan penghentian semua klaim atau keadaan perang. Resolusi Dewan Keamanan 338, menyerukan negosiasi damai antara pihak-pihak terkait. Pada 1974, Majelis Umum PBB mengeluarkan resolusi yang menegaskan kembali hak-hak rakyat Palestina untuk menentukan nasib sendiri, mencapai kemerdekaan nasional, kedaulatan, dan hak untuk kembali ke tanah air mereka. Tahun berikutnya, Majelis Umum membentuk Committee on the Exercise of the Inalienable Rights of the Palestinian 
People dan memberikan status observer (pengamat) kepada PLO di Majelis Umum dan berbagai konferensi yang diadakan PBB (un.org).

\section{Isu Permukiman Israel di Tepi Barat dan Yerusalem Timur}

Di antara berbagai masalah besar yang dihadapi warga Palestina, selain belum terpenuhinya hak asasi mereka untuk mendapatkan kemerdekaan dan kedaulatan, adalah terus dibangunnya permukiman Israel di dalam kawasan yang telah ditetapkan Resolusi 181 sebagai wilayah Palestina. Menurut laporan World Bank (2008), sejak pendudukan militer Israel atas Tepi Barat tahun 1967, sangat banyak permukiman Yahudi yang dibangun di Tepi Barat, meskipun hal ini melanggar hukum internasional. Seiring dengan itu, populasi pemukim Israel juga terus bertambah, diperkirakan mencapai 461.000 orang pada tahun 2007. Posisi permukiman itu mengisolasi secara sosial dan ekonomi seperempat juta warga Palestina di Tepi Barat. Dengan perkiraan tingkat rata-rata tahunan 3,44\% pada periode 2003-2007, tingkat pertumbuhan populasi pemukim hampir dua kali lipat dari populasi keseluruhan Israel selama periode yang sama (1,79\%). Selain itu, tanah yang disiapkan untuk perluasan permukiman di masa depan bahkan melampaui kebutuhan populasi pemukim yang tumbuh cepat. Selama 20 tahun pertama pendudukan, jumlah permukiman tumbuh pesat hingga mencapai total 129 pada tahun 1987; setelah itu, pertumbuhan mereka melambat; pada tahun 2005 ada sekitar 150 permukiman. Namun, total populasi pemukim dan daerah yang dikendalikan oleh permukiman terus tumbuh pesat. Antara 1987 dan 2005 populasi pemukim tumbuh lebih dari $150 \%$ dan wilayah daratan dikuasai oleh permukiman lebih dari $400 \%$.

Berikut ini data yang menunjukkan berkurangnya area Tepi Barat dan Yerusalem Timur yang dapat digunakan oleh warga Palestina.

Tabel 1: Berkurangnya Area yang Bisa Digunakan Warga Palestina

\begin{tabular}{|l|l|l|}
\hline Area yang Dibatasi & Area (hektar) & $\begin{array}{l}\text { \%dari Tepi Barat } \\
\text { (termasuk Jerusalem } \\
\text { Timur) }\end{array}$ \\
\hline $\begin{array}{l}\text { Permukiman dan kawasan industri di luar } \\
\text { batas. }\end{array}$ & 17.531 & 3,1 \\
\hline Posko Israel di luar batas & 1.131 & 0,2 \\
\hline
\end{tabular}




\begin{tabular}{|l|l|l|}
\hline $\begin{array}{l}\text { Tanah pertanian di luar permukiman di } \\
\text { luar batas }\end{array}$ & 10.179 & 1,8 \\
\hline $\begin{array}{l}\text { Total tanah yang disediakan untuk } \\
\text { pemukim Yahudi }\end{array}$ & 28.841 & 5,1 \\
\hline $\begin{array}{l}\text { Tanah yang disediakan untuk kawasan } \\
\text { militer dan cagar alam }\end{array}$ & 127.803 & 22,6 \\
\hline Jaringan jalan terbatas [untuk pemukim] & 2262 & 0,4 \\
\hline Tanah di barat Tembok Pemisah & 57.681 & 10,2 \\
\hline $\begin{array}{l}\text { Total tanah yang tidak bisa diakses warga } \\
\text { Palestina }\end{array}$ & 216.587 & 38,3 \\
\hline
\end{tabular}

Sumber: World Bank (2008)

Pembangunan permukiman itu seringkali disertai perampasan tanah dan rumah warga Palestina. Di grafik berikut ini terlihat jumlah rumah warga Palestina yang dihancurkan pada periode September 1993-November 2015.

\section{Grafik 1: Rumah yang Dihancurkan pada September 1993-November 2015}

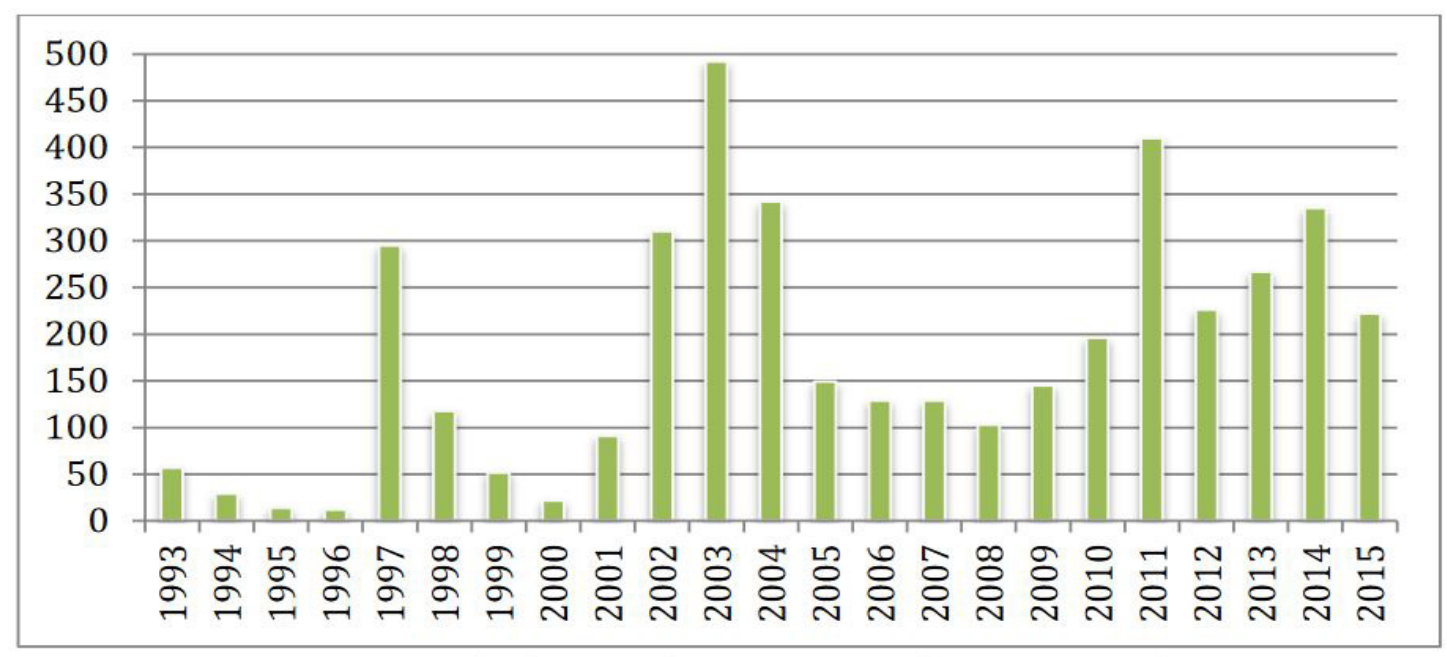

Sumber: Applied Research Institute Jerusalem - ARIJ (2015: 35)

Israel menggunakan kekuatan militernya dalam membangun dan memfasilitasi permukiman tersebut. Menurut DeGarmo dan Issac (2015) dari Applied Research Institute Jerusalem, Israel memberlakukan perintah militer (military order) yang terdiri dari 5 kategori besar:

1. Aneksasi Yerusalem Timur dan Dataran Tinggi Golan ke dalam wilayah Israel. 
2. Menciptakan aneksasi de facto di wilayah lain di kawasan pendudukan dengan cara menciptakan seperangkat sistem pemerintahan, peradilan dan keamanan khusus untuk permukiman Israel.

3. Menggantikan lembaga-lembaga pemerintahan, peradilan, dan keamanan Arab (Yordania di Tepi Barat, Mesir di Gaza) dengan komite militer Israel atau komite yang sepenuhnya dikendalikan oleh militer.

4. Menciptakan jaringan perizinan dan lisensi yang mengendalikan setiap aspek ekonomi Palestina.

5. Membatasi warga Palestina dengan cara membangun permukiman Israel dan jalan khusus untuk warga/pemukim Israel; membangun zona militer tertutup dan cagar alam; pembangunan Tembok Pemisah; dan memasang posko militer di seluruh wilayah pendudukan Palestina.

\section{Grafik 2: jumlah military order yang ditetapkan oleh pemerintah Israel pada periode 1995-2015.}

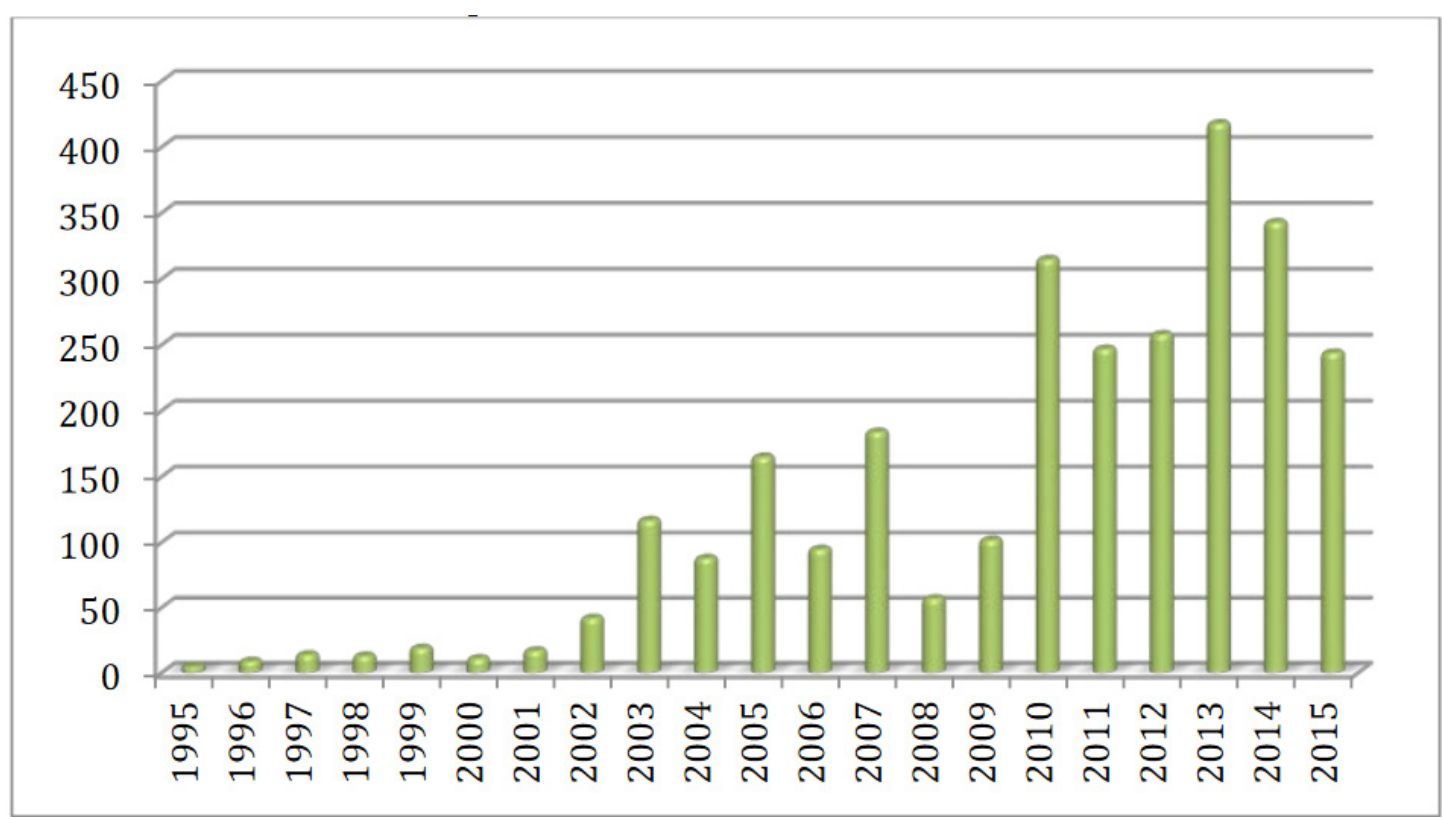

Sumber: Applied Research Institute Jerusalem - ARIJ (2015: 33)

Laporan terbaru (tahun 2019) menunjukkan bagaimana pemerintah Israel telah merencanakan apa yang disebutnya sebagai "upaya untuk menegakkan kedaulatan Israel" di daerah Lembah Jordan dan Laut Mati utara yang merupakan sepertiga wilayah Tepi Barat. Dalam sebuah konferensi pers, Netanyahu menegaskan Dataran 
Tinggi Golan dan Laut Mati utara sebagai perbatasan timur Negara Israel. Netanyahu juga menyatakan bahwa Sungai Yordan yang memisahkan Yordania dari Israel dan Tepi Barat, dan mengalir ke Laut Mati dari Danau Galilea sebagai penghalang alami dan aset strategis yang penting untuk memastikan keamanan Israel, sekaligus mencegah penyelundupan senjata oleh militan Palestina ke Tepi Barat. Dengan demikian, kawasan ini juga harus dikuasai oleh Israel. Menurut kelompok hak asasi manusia Israel, B'TSelem, Lembah Yordan dan Laut Mati utara terdiri hampir 30 persen dari Tepi Barat, yang sebagian besarnya sudah berada di bawah kendali Israel (Republika, 2019a).

Data terbaru, sejak Trump berkuasa 2017 hingga tahun 2019, pemerintah Israel menyetujui pembangunan 1.861 unit rumah di Yerusalem Timur. Jumlah itu meningkat $60 \%$ dibandingkan dua tahun sebelumnya. Jumlah ini merupakan yang tertinggi sejak 2000. Peningkatan jumlah pemukim Yahudi di Yerussalem Timur itu memiliki konsekwensi berkurangnya kawasan permukiman warga Palestina. Banyak kawasan-kawasan yang sejak semula dihuni oleh warga Palestina, kini menjadi kawasan permukiman Yahudi. Orang-orang Palestina sendiri kemudian ditempatkan di kawasan lain Yerussalem Timur yang masih dihuni oleh warga Palestina. Saat ini, terdapat sekitar 215 ribu Yahudi yang tinggal di Yerusalem Timur. Sementara 340 ribu warga Palestina tinggal di kawasan yang makin sempit (Republika, 2019b).

\section{Laporan Human Rights Council (Dewan HAM) PBB}

Pada Februari 2013, Dewan HAM PBB merilis laporan misi pencari fakta internasional independen yang ditugaskan untuk menyelidiki implikasi permukiman Israel terhadap warga Palestina di bidang sipil, politik, hak ekonomi, sosial dan budaya (Human Rights Council, 2013).

Dalam laporan tersebut disebutkan bahwa sejak tahun 1967, pemerintah Israel secara terbuka memimpin dan berpartisipasi secara langsung dalam pembangunan permukiman Israel tersebut. Antara lain yang dilakukan Israel adalah membangun infrastruktur; mendorong kaum migran Yahudi hidup di permukiman; mensponsori kegiatan ekonomi; mendukung permukiman melalui penyampaian layanan publik dan proyek pengembangan; dan merebut tanah Palestina. Sebagian milik warga dijadikan wilayah militer atau didaftarkan sebagai tanah negara. Anggaran dana pembangunan permukiman itu, selain investasi pemerintah, juga berasal dari bebagai NGO dan Organisasi Zionis Dunia (Human Rights Council, 2013). 
Selanjutnya laporan Dewan HAM PBB menyebutkan bahwa populasi pemukim Yahudi di Tepi Barat telah tumbuh empat kali lebih cepat daripada pertumbuhan populasi di kawasan Israel sendiri sejak 1995. Pada tahun 2004, Mahkamah Internasional menyatakan bahwa pembangunan permukiman Israel di kawasan Palestina adalah ilegal.

Menurut Dewan HAM PBB, ada 3 jenis implikasi yang dialami warga Palestina akibat permukiman ilegal:

(1) Terlanggarnya hak menentukan nasib sendiri (right to self-determination)

(2) Terlanggarnya hak keadilan dan hak tidak didiskriminasi (equality and right to non-discrimination)

(3) Kerugian bisnis.

Terkait dampak pertama, antara lain Dewan HAM PBB menyatakan, permukiman ilegal Israel telah melanggar hak rakyat Palestina untuk menentukan nasib sendiri, termasuk hak untuk memiliki keberadaan demografis dan teritorial di wilayah mereka sendiri dan hak untuk memiliki kedaulatan atas sumber daya alam di sana. Selain itu, langkah Israel yang melakukan pemindahan warga Israel ke wilayah Palestina adalah melanggar hukum humaniter internasional dan hukum pidana internasional.

Terkait dampak jenis kedua, Dewan HAM PBB melaporkan berbagai pelanggaran yang dilakukan Israel, antara lain: orang-orang Palestina secara rutin mengalami penangkapan dan penahanan sewenang-wenang oleh tentara Israel. Diperkirakan lebih dari 700.000 warga Palestina di Tepi Barat, termasuk anak-anak, telah ditahan militer Israel, dan sebagiannya di penjara yang berlokasi di Israel. Pada 2012, ada 4.100 warga Palestina yang ditahan, di antaranya 143 orang lanjut usia dan anak di bawah umur. Sistem pengadilan militer yang diberlakukan di Tepi Barat tidak menjamin keadilan bagi warga Palestina. Anak-anak kecil ditangkap di desa di dekat permukiman atau di jalan yang digunakan oleh tentara atau pemukim. Setelah ditangkap, mereka menghadapi banyak pelanggaran HAM. Sekitar 90 persen anakanak mengaku bersalah dan diberi hukuman penjara. Misi HAM PBB mendapatkan laporan kesaksian bahwa mengaku bersalah adalah jalan keluar tercepat dari sistem peradilan Israel meskipun mereka tidak melakukan pelanggaran. Sekitar 60 persen anak-anak Palestina menjalani hukuman di penjara Israel.

Sebaliknya, para pemukim tidak mendapatkan sanksi hukum ketika melakukan berbagai serangan kepada sekolah dan kekerasan kepada anak-anak Palestina dalam perjalanan mereka ke sekolah. Anak-anak itu harus dikawal tentara Israel dalam 
perjalanan ke dan dari sekolah untuk melindungi mereka dari serangan pemukim. Namun, pengawalan itu tidak selalu disediakan oleh tentara Israel.

Dengan demikian, menurut Dewan HAM PBB, secara tidak terbantahkan, rakyat Palestina telah mengalami pelanggaran atas hak mereka untuk diperlakukan secara non-diskriminatif, kesetaraan di hadapan hukum, dan hak untuk mendapatkan perlindungan hukum yang setara.

Sementara itu, implikasi terkait bisnis, laporan Dewan HAM PBB menyebutkan bahwa di satu sisi pembangunan permukiman Israel di Tepi Barat membawa keuntungan bagi bisnismen (kontraktor) Israel, namun di saat yang sama pembangunan permukiman itu telah menggunakan sumber daya alam, khususnya air dan tanah, yang merugikan warga Palestina. Selain itu, proyek pembangunan tersebut mendatangkan polusi. Israel juga membuang limbahnya ke desa-desa Palestina. Permukiman yang dibangun juga menghambat perekonomian warga karena terjadi pembatasan pergerakan dan kendala administratif dan hukum (Human Rights Council, 2013). Israel membangun penghalang, pagar, dan zona penyangga yang dimaksudkan untuk mengamankan para pemukim, namun berakibat membatasi kebebasan, pergerakan, dan perdagangan orang Palestina (Levingston, 2019).

Hal ini terkonfirmasi dalam pertemuan pribadi penulis dengan Menteri Luar Negeri Palestina, Dr. Riyad Al Maliki di Gedung Asia Afrika pada tanggal 13 Oktober 2018. Menurut Maliki, terdapat setidaknya 600 pos militer Israel (check point) yang bertebaran di seluruh wilayah Tepi Barat, di mana setiap harinya penduduk yang bergerak dari kediaman menuju tempat pekerjaan mereka, rata-rata diperiksa di 2 hingga 3 check point, dan menghadapi perilaku yang tidak manusiawi dari tentara Israel di setiap 10 kilometer wilayah pendudukan terebut (Wawancara dengan Menlu Palestina, 2018).

Saat ini ada sekitar 130 kompleks permukiman yang dibangun dengan seizin pemerintah Israel dan 100 permukiman tidak resmi. Total pemukim Yahudi di Tepi Barat sekitar 400.000 orang, dan jumlah populasi Palestina di kawasan itu adalah 2,6 juta orang (Levingston, 2019).

\section{Faktor Amerika Serikat}

AS secara konsisten mendukung Israel sejak dideklarasikan pada tahun 1948. Khusus terkait isu permukiman ilegal, menurut James Zogby (pendiri Arab-America Institute), salah satu pembicara dalam acara Arria-Formula Meeting yang digagas 
oleh Indonesia pada 9 Mei 2019 dan dipimpin oleh Menlu Retno Marsudi, telah terjadi 'erosi' dalam kebijakan luar negeri AS. Zogby mengatakan, bahwa AS awalnya menyebut permukiman itu “ilegal" namun kemudian menyebutkan "hambatan untuk perdamaian," lalu bergeser dengan memandang permukiman sebagai "rintangan untuk negosiasi" dan akhirnya berubah dari menentang "semua permukiman" menjadi menentang "dibangunnya permukiman baru". Pada November 2019, pemerintah AS menyatakan bahwa permukiman Israel di Tepi Barat tidak melanggar hukum internasional (Zogby, 2019).

Sejak Trump menjadi presiden AS, minimalnya ada 3 kebijakan luar negeri AS yang terkait dengan permukiman illegal ini:

1. Pada 5 Juni 2017 Kongres mengesahkan sebuah dokumen bernama Jerusalem Embassy and Recognition Act. Undang-Undang ini mendesak pemerintah Amerika Serikat untuk memindahkan Kedutaan Besar yang berada di Tel Aviv, untuk selanjutnya bertempat di Yerusalem, sekaligus sebagai pengakuan Yerusalem sebagai ibu kota Israel (Landler, 2017).

Pada 6 Desember 2017, secara resmi Trump mengumumkan bahwa AS mengakui (recognize) Yerusalem sebagai ibukota Israel. Pengakuan ini berdampak pada status 200.000 pemukim Israel di 12 kawasan di Yerusalem timur, kawasan yang sebenarnya telah ditetapkan sebagai ibu kota negara Palestina. Israel menduduki wilayah Yerusalem timur sejak 10 tahun yang lalu, dengan cara mengusir warga Palestina yang hidup di sana dan membangun permukiman ilegal.

2. Pada Maret 2019, Presiden Trump mengakui kedaulatan Israel atas Dataran Tinggi Golan yang secara de jure adalah wilayah Suriah yang diduduki Israel sejak 1967 pasca Perang Arab-Israel. Di kawasan itu ada 20.000 pemukim ilegal Yahudi. Berdasarkan pengakuan Trump ini, Perdana Menteri Israel, Benjamin Netanyahu dapat menjustifikasi penguasaan Israel atas Tepi Barat (Levingston, 2019).

3. Akhirnya, pada November 2019 pemerintah Trump menyatakan bahwa permukiman Israel di Tepi Barat tidak melanggar hukum internasional. Permukiman ini mengusik perdamaian dunia, karena jelas-jelas memperparah kehidupan masyarakat Palestina yang memburuk sejak tahun 1948, serta merusak suasana perdamaian di kawasan Timur Tengah, serta mengusik batin masyarakat dunia yang selama ini mengetahui Yerusalem sebagai pusat tiga agama Samawi, yakni Islam, Kristen, dan Yahudi. 
Menanggapi pengakuan sepihak AS atas Yerusalem sebagai ibu kota Israel, Dewan Keamanan PBB pada 18 September 2017 bersidang guna mengkaji sebuah resolusi yang dirancang oleh Mesir, yang pada intinya menentang sikap Amerika Serikat yang mengakui Yerusalem sebagai ibu kota Israel. Adapun rancangan resolusi tersebut adalah sebagai berikut:

Any decisions and actions which purport to have altered e character, status or demographic composition of the Holy City of Jerusalem have no legal effect, are null and void and must be rescinded in compliance with relevant resolutions of the Security Council, and in this regard calls upon all States to refrain from the establishment of diplomatic missions in the Holy City of Jerusalem.

Dalam perkembangan selanjutnya, 14 dari 15 anggota Dewan Keamanan PBB menyetujui resolusi tersebut, dan seperti biasanya Amerika Serikat menggunakan hak veto. Hasilnya, draft resolusi yang diajukan Mesir tersebut ditolak, walaupun mendapatkan dukungan 4 anggota tetap DK PBB dan 10 anggota tidak tetap DK PBB (UN, 2017a).

Langkah AS ini mendapatkan protes luas dari masyarakat internasional, termasuk Indonesia. Pemerintah dan masyarakat Indonesia telah lama mengkritisi Dewan Keamanan PBB yang didominasi Amerika Serikat, karena secara semenamena menggunakan hak veto yang dimilikinya, untuk membatalkan segala bentuk Resolusi Dewan Keamanan yang menguntungkan Palestina, karena dianggap membahayakan keberadaan Israel. Karena itulah, berbagai prakarsa yang dilakukan Republik Indonesia baik secara mandiri maupun bersama-sama negara lain dan organisasi kawasan, senantiasa dipadamkan oleh veto Amerika Serikat tersebut.

Menyikapi keadaan ini, pada tanggal 13 Desember 2017 diadakan Konferensi Tingkat Tinggi Luar Biasa Organisasi Konferensi Islam (OKI) di Istanbul, Turki. Indonesia mendukung penuh prakarsa ini. Sebelum pelaksanaan KTT tersebut, Menlu Retno Marsudi bertemu dengan Menlu Palestina Riyad Al Maliki, di Amman, Yordania (11 Desember 2017) di mana Menlu Retno menegaskan komitmen kuat rakyat dan pemerintah Indonesia untuk terus mendukung Palestina. Di hari yang sama Menlu Retno Marsudi juga bertemu dengan Menlu Yordania Ayman Safadi yang dimaksudkan untuk membahas persiapan KTT Luar Biasa OKI (Setkab, 2017).

Dalam KTT tersebut, Indonesia mengajak negara-negara yang mempunyai hubungan diplomatik dengan Israel untuk tidak memindahkan kantor kedutaannya dari Tel Aviv ke Yerusalem dan menyeru negara-negara anggota OKI yang memiliki hubungan dengan Israel agar mengambil langkah-langkah diplomatik, termasuk 
kemungkinan meninjau kembali hubungan dengan Israel. Selanjutnya, pasca KTT, Menlu Retno melakukan upaya diplomasi untuk mengajak berbagai negara, khususnya Uni Eropa, agar menolak klaim Amerika atas Yerusalem sebagai ibukota Israel, termasuk dengan menemui Menteri Luar Negeri Uni Eropa di Brussels (Waluyo, 2017).

Selanjutnya, pemerintah Indonesia mendukung prakarsa Turki dan Yaman yang masing-masing merupakan perwakilan OKI dan Liga Arab, dalam meminta Majelis Umum PBB mengadakan sebuah Emergency Special Session berupa sebuah Sidang Umum PBB pada 21 Desember 2017 untuk menengahi krisis tersebut. Sikap ini juga merupakan respon terhadap kegagalan Dewan Kemanan PBB yang tidak pernah bulat dalam pengambilan keputusan mengenai status Yerusalem. Dalam persidangan tersebut, 128 negara secara resmi menyatakan bahwa Yerusalem berada dalam wilayah Palestina, 35 negara mengambil sikap abstain, dan 9 negara menentang, yakni Honduras; Guatemala; Marshall Islands; Nauru; Negara Federasi Micronesia; Togo; Palau; Israel; dan Amerika Serikat (UN, 2017b).

Selanjutnya negara-negara yang mendukung Palestina di Majelis Umum PBB meminta semua peserta sidang mematuhi resolusi yang telah disetujui mengenai status Yerusalem tersebut. Namun mengingat resolusi tersebut bersifat tidak mengikat, dan kekuatannya berada di bawah resolusi Dewan Keamanan PBB, maka negara-negara dibebaskan untuk menentukan sikap mereka. Keadaan seperti inilah yang memicu Republik Indonesia dan negara-negara di Asia Afrika untuk terus merombak PBB, sehingga benar-benar mewakili kemajemukan masyarakat di dunia. Adapun pemikiran yang selama ini dikemukakan Republik Indonesia adalah mengedepankan prinsip-prinsip seperti keluasan wilayah, jumlah penduduk, peradaban, kemajuan pembangunan, dan kemampuan mensenyawakan pemikiran lokal dangan demokrasi modern.

Walaupun ide-ide Indonesia dan mayoritas negara di dunia menemui kegagalan, sikap Indonesia adalah konsisten. Hal ini terbukti dari penyelenggaraan Solidarity Week for Palestine yang diselenggarakan pada 13-17 Oktober 2018, dengan dihadiri oleh Menlu Palestina, Riyad Al Maliki. Kegiatan ini melibatkan berbagai lembaga pemerintah, organisasi internasional, organisasi non-pemerintah untuk kemanusiaan, tokoh lintas agama, para filantropi, dan anggota masyarakat pada umumnya. Menurut Menlu Marsudi, Pekan Solidaritas untuk Palestina ini "adalah bentuk komitmen berkelanjutan Indonesia terhadap Palestina untuk meningkatkan pemahaman dan kepedulian rakyat Indonesia tentang perjuangan rakyat Palestina" (Antaranews, 2018). 


\section{Peranan Diplomat Indonesia dalam Memperjuangkan Palestina di PBB di Masa Presidency of the UNSC (Mei 2019)}

Konsistensi RI dalam mendukung Palestina tercermin dalam sebuah Pernyataan Pers Tahunan Menteri Luar Negeri RI, Retno Marsudi di bulan Januari 2019 di Jakarta sebagai berikut, "Palestina sebagai jantung politik luar negeri Indonesia, setiap helaan napas diplomasi Indonesia, di situ terdapat perjuangan untuk Palestina." Dijelaskan juga jika dukungan ini tidak hanya berupa dukungan politik, namun juga berupa dukungan ekonomi, kerja sama teknis, kesehatan, dan pendidikan untuk membangun Palestina secara proporsional. Lebih jauh Menlu RI menjelaskan perihal pembebasan tarif masuk dari sejumlah produk asal Palestina ke Indonesia (Marsudi, 2019).

Mulai tanggal 1 Januari 2019 hingga 31 Desember 2020, Indonesia terpilih sebagai salah satu anggota Dewan Kemanan PBB, dan antara tanggal 1 sampai 31 Mei 2019 Indonesia mendapatkan kepercayaan untuk bertindak sebagai presidensi dewan tersebut. Kesempatan ini digunakan sepenuhnya oleh Indonesia untuk mengemukakan ide-ide besarnya bagi perdamaian dunia.

Dengan mengangkat tema "Menabur Benih Perdamaian" (Investing in Peace), Republik Indonesia menyelenggarakan serangkaian kegiatan utama seperti: (a) Sidang Terbuka mengenai Misi Pemeliharaan Perdamaian PBB; (b) Sidang Terbuka mengenai Perlindungan Warga Sipil dalam Konflik Bersenjata; (c) Diskusi Informal Arria-Formula mengenai Palestina. Dalam perkembangannya, perwakilan RI di PBB melakukan berbagai kegiatan yang sangat luas seperti 15 briefing terbuka, 14 konsultasi tertutup, 2 sidang terbuka tingkat menteri, 3 pertemuan Arria-Formula yang secara khusus membahas pembangunan permukiman ilegal Israel di wilayah pendudukan Palestina (Kemenlu Rl, 2019b).

Pada tanggal 22 Mei 2019, para diplomat Indonesia di PBB menyelenggarakan UN Security Council Briefing yang khusus membahas isu Timur Tengah. Briefing yang dipimpin oleh Menlu Retno Marsudi itu dihadiri oleh semua anggota Dewan Keamanan PBB. Target briefing adalah menemukan informasi terkait dengan situasi terbaru di Timur Tengah, termasuk Palestina, Suriah, dan Yaman. Pada pertemuan itu, situasi Palestina mendapat perhatian khusus dari Indonesia. Menteri Luar Negeri Indonesia menyatakan bahwa situasi di Palestina memburuk sejak Januari lalu karena sejumlah kasus, termasuk kekerasan yang terjadi pada bulan Mei, pelarangan kehadiran organisasi internasional di Hebron oleh Israel, dan berlanjutnya pembangunan permukiman ilegal di wilayah Palestina. 
Dalam briefing ini, Menteri Marsudi menekankan tiga hal penting, yaitu urgensi untuk memberikan perlindungan bagi warga sipil Palestina. Kedua, mendesak komunitas internasional untuk mengambil tindakan nyata untuk menangani masalah kemanusiaan di Palestina, khususnya peningkatan kondisi ekonomi dan sosial di Palestina. Ketiga, pentingnya melanjutkan proses negosiasi damai yang kredibel dan memastikan keadilan bagi semua pihak melalui negosiasi (Kemenlu RI, 2019c).

Khusus tentang isu permukiman ilegal Israel, pemerintah Indonesia telah mengeluarkan pernyataan tegas, yaitu seruan penghentian segera pembangunan permukiman ilegal tersebut. Dalam pertemuan yang digagas diplomat Indonesia di PBB yang diberi nama "Arria Formula meeting" dengan tema "Israeli Settlements and Settlers: Core of the Occupation, Protection Crisis, and Obstruction of Peace, Menlu Retno menyatakan, ekspansi berkelanjutan Israel dengan pembangunan permukiman ilegal di wilayah Palestina tidak dapat diterima (unacceptable). Menlu Retno mengemukakan statistik bahwa permukiman ilegal Israel telah berlipat ganda dari sekitar 110.000 pada September 1993 menjadi 620.000 pada akhir 2017 dan hal ini merupakan penghalang utama proses perdamaian antara Israel dan Palestina.

Ada 3 poin utama yang disampaikan Menlu Retno terkait permukiman ilegal ini, yaitu:

(1) pembangunan permukiman ilegal di wilayah Palestina termasuk diYerusalem Timur semakin mengurangi harapan solusi dua negara;

(2) pembangunan permukiman ilegal adalah sumber dari berbagai pelanggaran hukum dan hak asasi manusia terhadap rakyat Palestina;

(3) komunitas internasional memiliki tanggung jawab bersama untuk mengakhiri kebijakan permukiman ilegal Israel.

Untuk itu, Menlu Retno menekankan pentingnya tekanan publik dari komunitas internasional untuk mengakhiri pembangunan permukiman ini dan salah satu cara untuk mempertahankan perhatian komunitas internasional terhadap masalah permukiman adalah dengan menetapkan hari solidaritas internasional terhadap para korban permukiman ilegal (Setkab, 2019).

Dari berbagai upaya diplomasi para diplomat Indonesia itu terlihat ada beberapa hasil positif, di antaranya, pertama, Majelis Umum PBB pada tanggal 14 November menekankan adanya kedaulatan Palestina atas sumber daya alam (UN, 2019a). Kedua, Majelis Umum PBB pada tanggal 3 Desember 2019 mengeluarkan 5 resolusi perihal 
Timur Tengah, yang di dalamnya memuat desakan pada negara-negara anggota PBB untuk tidak mengakui perubahan status Yerusalem, kecuali melalui negosiasi dan sepersetujuan berbagai pihak yang terlibat (UN, 2019b).

Konsistensi Republik Indonesia yang mendukung Palestina secara terus menerus di atas, berdampak pada tekanan Amerika Serikat pada Indonesia. Adapun tekanan tersebut antara lain adalah sebagai berikut. Pertama, ancaman embargo persenjataan, seandainya Indonesia jadi membeli pesawat tempur Sukhoi-35 dari Rusia. Kedua, ancaman pemberlakuan tarif baru atas produk impor asal Indonesia, dengan alasan bahwa tarif lama mencerminkan aturan perdagangan yang tidak adil, sehingga menyebabkan ruginya catatan perdagangan bilateral. Ketiga, seringnya mengeluarkan Travel Warning/peringatan berkunjung ke Indonesia, dalam hal terjadinya masalah keamanan di dalam negeri Indonesia. Keempat, larangan berkunjung bagi petinggi TNI, walaupun telah mendapatkan undangan resmi dari pemerintah Amerika Serikat sendiri. Kelima, penambahan syarat visa bagi wisatawan asal Indonesia yang akan mengunjungi situs-situs bersejarah di Jerusalem.

Namun tekanan ini tidak menyurutkan langkah Indonesia untuk terus membela Palestina. Dari berbagai uraian di atas, terlihat bahwa karakter "bastion of revolutionliberator" masih melekat sebagai national role conception Indonesia. Pemerintah Indonesia, termasuk di dalamnya para diplomat Indonesia di PBB, tetap konsisten berpendapat bahwa mereka memiliki tugas untuk mengatur atau memimpin gerakan untuk membebaskan pihak lain dari penjajahan (kolonialisme) serta memberikan dukungan fisik, moral, dan inspirasi ideologis kepada Palestina. Sumber dari national role conception Indonesia adalah ideological principles dan anti-colonial attitudes yang tertuang dalam Pembukaan UUD 45 yaitu "turut serta mewujudkan perdamaian dunia serta menghapuskan penjajahan".

Selain dipengaruhi oleh self-defined national role conceptions, role performance Indonesia terkait isu Palestinajuga sejalan dengan the role prescriptions terkait prinsipprinsip hukum umum dan komitmen terhadap perjanjian internasional. Permukiman ilegal secara resmi telah dinyatakan ilegal oleh Mahkamah Internasional pada tahun 2004 sehingga penolakan tegas Indonesia adalah upaya penegakan hukum internasional. Selain itu, Indonesia juga telah menerima faktor keempat terkait peran negara, yaitu siap dengan konsekuensi atas pilihan kebijakan yang diambilnya.

Karena itu, sangat beralasan ketika Menteri Luar Negeri Palestina dalam pembicaraan pribadinya dengan penulis menyatakan bahwa bangsa Palestina memahami sepenuhnya, jika hanya Indonesia yang dapat mewakili aspirasi Palestina. 
Karena itulah Palestina memberikan kepercayaan yang seluas-luasnya pada Indonesia untuk menjalankan amanah tersebut. Menteri Luar Negeri Palestina dalam acara Indonesian Solidarity Week for Palestine (Oktober 2018) di Gedung Asia Afrika mengikuti saran kami selaku moderator untuk bersama-sama masyarakat umum di Gedung tersebut, meneriakkan kalimat:' kalimat, "Palestina harus merdeka!"

\section{Kesimpulan}

Hubungan antara bangsa Indonesia dan bangsa Palestina terjalin erat awal masa kemerdekaan Indonesia. Sejak era Presiden Sukarno hingga masa pemerintahan Presiden Joko Widodo, posisi Indonesia tidak pernah berubah, selalu mendukung kemerdekaan bangsa Palestina. Pada bulan Mei 2019, Indonesia menjabat sebagai Presiden Dewan Keamanan PBB dan kesempatan tersebut digunakan para diplomat Indonesia di PBB untuk menggalang dukungan penuh bagi Palestina. Melalui tema "Investing in Peace" para diplomat Indonesia berusaha menarik perhatian komunitas internasional untuk kembali peduli kepada Palestina.

Para masa presidensi Indonesia di Dewan Keamanan PBB, para diplomat Indonesia antara lain mengadakan UN Security Council Briefing di mana Menteri Luar Negeri Indonesia secara khusus menekankan fakta mengenai memburuknya kondisi Palestina, antara lain akibat berlanjutnya pembangunan permukiman ilegal di wilayah Palestina. Selain itu, para diplomat Indonesia mengadakan ArriaFormula Meeting on the Palestinian Issue yang menekankan pentingnya dunia internasional menyelesaikan kasus pelanggaran hukum internasional di Palestina yaitu pembangunan permukiman ilegal (illegal settlements) di kawasan pendudukan Palestina.

Dianalisis dengan menggunakan national role conceptions yang dikemukakan Holsti (1970), terlihat bahwa role performance Indonesia terkait Palestina didasari oleh national role conceptions sebagai bastion of revolution liberator atau sebagai bangsa yang ingin menghapuskan penjajahan di negara lain, yaitu Palestina. Hal ini didorong oleh the role prescriptions, yaitu komitmen pada penegakan perjanjian internasional, di mana Mahkamah Internasional telah menetapkan bahwa pembangunan permukiman Israel di wilayah pendudukan Palestina (occupied Palestine) adalah ilegal. Meskipun Indonesia menghadapi beberapa konsekuensi berat atas pilihan kebijakan yang diambilnya, Indonesia tetap konsisten pada national role conceptionsnya. 


\section{Daftar Pustaka}

Antara News. (2018). Indonesian foreign ministry holds solidarity week for Palestine. [Online] Dalam https://en.antaranews.com/news/119536/indonesian-foreignministry-holds-solidarity-week-for-palestine [Diakses 15 Des 2019]

Applied Research Institute Jerusalem. (2015). The Israeli Settlement Enterprise: Grave Breaches of International Law [online] https://www.arij.org/files/arijadmin/Final_ Draft_ICC_Settlements_1_opt.pdf [Diakses 13 Des 2019].

BBC News. (2015). Palestinian flag raised at United Nations headquarters. [online] Dalam: https://www.bbc.com/news/world-middle-east-34398174 [Diakses 13 Des 2019].

DeGarmo, D. dan Issac, J. (2015). The Israeli Settlement Enterprise: Grave Breaches of International. [online]. Dalam: https://www.arij.org/files/arijadmin/Final_Draft_ ICC_Settlements_1_opt.pdf [Diakses 10 Des 2019].

Holsti, K.J. (1970). National Role Conceptions in the Study of Foreign Policy. International Studies Quarterly, 14(3), 233-309.

Human Rights Council. (2013). Report of the independent international fact-finding mission to investigate the implications of the Israeli settlements on the civil, political, economic,social and cultural rights of the Palestinian people throughout the Occupied Palestinian Territory, including East Jerusalem. Dalam: https:// www.ohchr.org/Documents/HRBodies/HRCouncil/RegularSession/Session22/AHRC-22-63_en.pdf [Diakses 10 Des 2019].

Kemenlu RI. (2019a). Kemitraan Strategis Baru Asia Afrika (NAASP). [online] Dalam: https://kemlu.go.id/portal/i/read/165/halaman_list_lainnya/kerjasamakemitraan-strategis-baru-asia-afrika-naasp-latar-belakang [Diakses 13 Des 2019].

Kemenlu RI. (2019b). Presidensi Indonesia pada Dewan Keamanan PBB Mei 2019: Menabur Benih Perdamaian. Jakarta Pusat: Direktorat Jenderal Kerja Sama Multilateral. https://kemlu.go.id/portal/id/page/61/keanggotaan_indonesia_ pada_dk_pbb (dokumen PDF) [Diakses 10 Des 2019].

Kemenlu RI. (2019c). FM Marsudi Chairs The UN Security Council Meeting Discussion Situation in The Middle East. [online] Dalam: https://kemlu.go.id/portal/en/ $\mathrm{read} / 307 /$ view/menlu-ri-pimpin-pertemuan-dewan-keamanan-pbb-mengenaisituasi-di-timur-tengah [Diakses 13 Des 2019]. 
Landler, M. (2017). Trump to Keep Embassy in Tel Aviv, but Recognize Jerusalem as Capital. The New York Times [online]. Dalam: https://www.nytimes. com/2017/12/01/us/politics/trump-embassy-israel-jerusalem.html [Diakses 13 Des 2019].

Levingston, I. (2019). Israeli Settlements. Bloomberg. [online] Dalam: https://www. bloomberg.com/quicktake/israeli-settlements [Diakses 13 Des 2019].

Marsudi, R. L. (2019). Pernyataan Pers Tahunan Menteri Luar Negeri Indonesia. Jakarta: Kementerian Luar Negeri Indonesia.

Ministry of Foreign Affairs of the Republic of Indonesia. (2019). Special Issues: The Palestinian Issue. Dalam: https://kemlu.go.id/portal/en/read/23/halaman_list_ lainnya/the-palestinian-issue [Diakses 13 Des 2019].

Republika. (2019a). Menengok Kondisi Tepi Barat yang Ingin dicaplok Netanyahu. [online]. Dalam: https://internasional.republika.co.id/berita/pxoewt366/ menengok-kondisi-tepi-barat-yang-ingin-dicaplok-netanyahu[Diakses 13 Des 2019].

Republika. (2019b). Permukiman Yahudi di Yerusalem Timur Melonjak. [online]. Dalam: https://internasional.republika.co.id/berita/pxs2kl382/permukiman-yahudi-diyerusalem-timur-melonjak [Diakses 13 Des 2019].

Siadari, E. (2015) Menlu RI Hadiri Pengibaran Bendera Palestina di PBB. Satu Harapan [online] Dalam: http://www.satuharapan.com/read-detail/read/menlu-ri-hadiripengibaran-bendera-palestina-di-pbb [Diakses 13 Des 2019].

Setkab. (2017). Bertemu Menlu Palestina, Menlu Retno Tegaskan Komitmen Indonesia Dukung Kemerdekaan Palestina. [online] Dalam: https://setkab. go.id/bertemu-menlu-palestina-menlu-retno-tegaskan-komitmen-indonesiadukung-kemerdekaan-palestina/ [Diakses 10 Des 2019].

Setkab. (2019). Indonesia Calls for End to Illegal Israeli Settlement Expansion. [online] Dalam: https://setkab.go.id/en/indonesia-calls-for-end-to-illegal-israelisettlement-expansion/ [Diakses 13 Des 2019].

Tribunnews.com. (2015). Transkrip Lengkap Pidato Presiden Jokowi Saat Membuka KAA. [online] Dalam: https://pontianak.tribunnews.com/2015/04/23/transkriplengkap-pidato-presiden-jokowi-saat-membuka-kaa [Diakses 13 Des 2019]. 
United Nations (UN). (2017a). Middle East: Security Council fails to adopt resolution on Jerusalem. [Online] Dalam: https://news.un.org/en/story/2017/12/639772middle-east-security-council-fails-adopt-resolution-jerusalem [Diakses 20 Des 2019].

United Nations (UN). (2017b). General Assembly demands all States comply with UN resolutions regarding status of Jerusalem. [Online] Dalam: https://news.un.org/ en/story/2017/12/640152-general-assembly-demands-all-states-comply-unresolutions-regarding-status [Diakses 20 Des 2019].

United Nations (un.org). History of the Question of Palestine. [online] Dalam: https:// www.un.org/unispal/history/ [Diakses 13 Des 2019].

United Nations (UN). (2019a). Second Committee Approves 6 Resolutions, including on Compensation for Oil Slick off Lebanon's Coast, Sovereignty of Palestinians over Their Natural Resources. Dalam https://www.un.org/press/en/2019/ gaef3526.doc.htm [Diakses 20 Des 2019].

United Nations (UN). (2019b). General Assembly Adopts 5 Resolutions on Middle East, including Text Urging States Not to Recognize Changes on Status of Jerusalem, Pre-1967 Borders. [online] Dalam: https://www.un.org/press/en/2019/ga12220. doc.htm [Diakses 13 Des 2019].

Waluyo, A. (2017). KTT Luar Biasa OKI Desak PBB Keluarkan Resolusi Tolak Keputusan AS soal Yerusalem. VOA Indonesia. Dalam https://www.voaindonesia. com/a/ktt-luat-biasa-oki-desak-pbb-keluarkan-resolusi-tolak-klaim-as-atasyerusalem/4163586.html. [Diakses 13 Des 2019].

Wawancara dengan Menteri Luar Negeri Palestina, Dr. Riyad Al Maliki, di Bandung, 13 Oktober 2018.

World Bank. (2008). West Bank and Gaza The Economic Effects of Restricted Access to Land in the WestBank. Laporan"TheWorldBankSocialandEconomicDevelopment GroupFinanceandPrivateSectorDevelopmentMiddleEastandNorthAfricaRegion". [online]. Dalam: http://siteresources.worldbank.org/INTWESTBANKGAZA/ Resources/EconomicEffectsofRestrictedAccesstoLandintheWestBankOct.20,08. pdf [Diakses 10 Des 2019].

Zogby, J.J. (2019). US Complicity in Israel's Violations of International Law. Dalam https://www.aaiusa.org/us_complicity_in_israel_s_violations_of_international_ law [Diakses 10 Des 2019]. 